\title{
MOTIVASI BELAJAR PENDIDIKAN AGAMA ISLAM BAGI ANAK YATIM PIATU DALAM TINJAUAN SOSIAL
}

\author{
Rustina
}

\begin{abstract}
In general, social conditions affect children's activities and motivation in studying. Related to the issue, the discussion in this paper sees that children are a gift from Allah SWT that is always expected by every appropriate guidance with social development both in society and in family. However, not everyone can look after their children properly according to what is ordered by Allah SWT through religious teachings. For various causes and reasons, parents do not pay attention to the religious education of their children. In the end, the negative impact will be strongly felt by parents, especially for the children themselves. In order to forming religious education in children in these conditions, the community involvement is needed as a social element. The main factors influencing learning motivation of orphans are the factor from within (internal) and from outside (external). But the most fundamental is child psychology which is something that is not separated from human life itself, so that these condition of social differences become the most influencing factor for the orphans and neglected children in doing their learning activities. Thus, the conclusion is that social conditions are something highly determines the learning motivation that can change the level of selfconfidence for the orphans. Hence, the cooperation of the government and observers of society condition must keep on trying to provide the supports in the form of attention, affection, guidance and also try to develop abilities and shape characters of the children, which are not only their intellectual capability but also their moral through various forms of religious education.
\end{abstract}

Keywords: Motivation for Islamic Religious Education, Orphans, Social.

\section{PENDAHULUAN}

Anak adalah anugerah dari Allah SWT yang selalu diharapkan oleh setiap bimbingan sesuai dengan perkembangan sosial baik dalam masyarakat maupun dalam keluarga. Namun, tidak semua orang (orang tua) dapat menjaga dan mengasuh anak-anaknya dengan baik sesuai dengan apa yang diperintahkan olehAlllah SWT melalui ajaran-ajaran agama. Karena berbagai sebab dan alasan, orang tua tidak menghiraukan lagi pendidikan agama anak. Pada akhirnya, dampak negatifnya akan sangat dirasakan oleh orang tua lebih-lebih bagi pribadi anak sendri. Untuk dapat membentuk pendidikan beragama pada anak, ibu sebagai orang pertama yang dikenal anak, maka ibu perlu memberi pemahaman terhadap dimensi keagamaan pada anak merupakan hal penting, Anak pada 
182 | MUSAWA, Vol. 12 No.2 Desember 2020 : 181-206

hakikatnya merupakan amanat dari Allah SWT yang harus disyukuri, dan kita sebagai muslim wajib mengemban amanat itu dengan baik dan benar. Cara mensyukuri karunia Allah tersebut yang berupa anak adalah dengan melalui merawat, mengasuh, dan mendidik serta membinaan karakter sebut dengan baik dan benar, agar mereka kelak tidak menjadi anak-anak yang lemah, baik fisik dan mental, serta lemah iman dan lemah kehidupan duniawinya.Tujuan dari pendidikan tersebut adalah menjadi seorang muslim yang sempurna, yang beriman dan bertakwa kepada Allah SWT. Ibu sebagai orang tua adalah pendidik pertama yang utama bagi anak, sebelum anak mengenal dunia luar, maka terlebih dahulu anak mengenal ibu dan setelah itu bapaknya yang merupakan orang terdekat bagi anak.Adapun usaha-usaha perempuan dalam membina kesadaran beragama anak sebagai berikut: membina pribadi anak, membentuk kebiasaan yang baik, membentuk kerohaniawan menjadi pribadi muslim dan membimbing anak dengan cara mendorong kepadahal-hal yang mengarah ketaatan kepada Allah Swt dan mendidik dengan berbagai macam ibadah. Seperti shalat, membaca alquran, shalat berjamah di rumah dan di sekolah sehingga secara alami lingkungan juga mempengaruhi motivaisi anak.

Kehidupan adalah sesuatu yang tidak hanya antara hidup dan mati melainkan bagaimana cara menjalani prosesnya dimana termasuk bersosialisasi di lingkungan keluarga, sekolah dan masyarakat. Rachmad K. Dwi Susilo memberikan penjelasan mengenai teori dominasi lingkungan yaitu:

Alam dan lingkungan memiliki kehendak atas manusia dan kehidupan manusia dikendalikan olehnya. Artinya sebagai kekuatan tersendiri, lingkungan memiliki sifat sangat menentukan kehidupan manusia. Alam dan lingkngan menentukan dan membentuk kepribadian, pola-pola hidup, organisasi sosial manusia, seperti model kehidupan sosial (pola pemukiman, cara bercocok tanam) masyarakat yang disesuaikan dengan lingkungan. ${ }^{1}$

Dalam ruang lingkup keluarga memiliki peran yang sangat besar bagi tumbuh kembang anak karena keluarga merupakan lingkungan pertama yang ditemui anak. Adapun struktur dalam keluarga yaitu: ayah, ibu, kakek, nenek, saudara, dan seterusnya.

\footnotetext{
${ }^{1}$ Rachmad K. Dwi Susilo, Sosiologi Lingkungan (Jakarta: RajaGrafindo Persada, 2008),
} 
Setiap anak memiliki hak yang sama dan terpenuhi segala kebutuhannya seperti hak untuk hidup dengan baik, mendapatkan kasih sayang, makan dan minum yang baik, pakaian yang baik serta hak memiliki pendidikan yang tinggi untuk meraih cita-citanya, karena anak merupakan generasi penerus agama dan bangsa yang harus di bentuk pribadi yang seperti diinginkan negara dan masyarakat.

Dalam membentuk karakter seorang anak memang tidak mudah, butuh kesabaran yang tinggi dan usaha yang maksimal serta dilakukan secara kontinu yang dimulai sejak anak masih kecil. Pemberian penghargaan disetiap perbuatan baik yang dilakukannya dan dorongan berupa motivasi sangat baik dalam mendidik anak.

Seperti kita ketahui bersama bahwa motivasi ada dua macam yaitu eksternal dan internal. Kedua motivasi ini sangat membantu dalam proses belajar anak, dimana anak akan lebih bersemangat dalam menggapai cita-cita mereka. Tidak dipungkiri bahwa banyak anak yang telah kehilangan orang tua dan kerabat, salah satunya seperti anak-anak Secara logika, anak akan terasa berat dalam menjalani kehidupan tanpa adanya sosok kedua orang tua yang mendampinginya tetapi apabila anak tersebut mendapatkan perlakuan yang sama dengan anak-anak lainnya tentu akan menjadi penyemangat bagi mereka yang telah kehilangan orang tua dan kerabatnya. Allah berfirman dalam Q.S. an-Nisaa (4): 9.

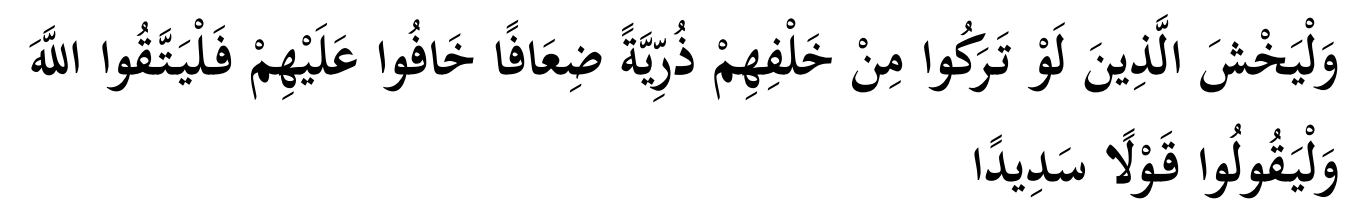

Terjemahnya: "Dan hendaklah takut kepada Allah orang-orang yang seandainya meninggalkan dibelakang mereka anak-anak yang lemah, yang mereka khawatir terhadap (kesejahteraan) mereka. oleh sebab itu hendaklah mereka bertakwa kepada Allah dan hendaklah mereka mengucapkan Perkataan yang benar.", (Q.S. an-Nisaa (4): 9)

Ayat di atas memerintahkan untuk takut kepada Allah karena dimanapun dan kapanpun Allah melihat dan mendengar setiap hamba-hamba-Nya serta

\footnotetext{
${ }^{2}$ Departemen Agama Republik Indonesia, Al-Qur'an dan Terjemahannya (Jakarta: CV. Atlas, 2000), 116.
} 
184 | MUSAWA, Vol. 12 No.2 Desember 2020 : 181-206

menjelaskan bahwa anak merupakan amanah yang harus di pelihara dengan sebaik mungkin termasuk di dalamnya anak yatim piatu, tidak meninggalkan mereka karena khawatir terhadap kesejahteraan hidupnya sendiri serta selalu bertakwa kepada Allah dan senantiasa berkata yang baik atau benar.

Berdasarkan uraian di atas maka perlu diketahui dan dipahami bahwa setiap anak terlahir dalam keadaan suci dengan memiliki kemampuannya masingmasing yang diberikan oleh Allah sejak lahir serta memiliki hak yang sama seperti anak pada umumnya memiliki orang tua, sanak saudara dan kerabat keluarga lainnya. Oleh karena itu Penulis terdorong untuk melihat kondisi sosial, aktivitas dan cara meningkatkan motivasi dalam belajar anak dalam tinjauan sosial.

\section{PEMBAHASAN}

\section{A. Kajian tentang Perkembangan Pendidikan Anak Yatim Piatu}

Manusia merupakan makhluk ciptaan Allah swt. yang paling sempurna dibandingkan makhluk-makhluk lainnya. Hal ini dapat terlihat jelas dari perkembangan manusia yang di dalamnya terdapat campur tangan Sang Pencipta dan manusia itu sendiri. "Usaha manusia untuk mengerti dirinya itu adalah usaha lebih jauh, atau termasuk bidang ontologi. Sebab sesungguhnya, pribadi manusia itu adalah suatu realita; yakni realita di dalam makrokosmus. Perbedaannya dengan realita yang lain di dalam alam semesta itu, walaupun relatif banyak, namun pada prinsipnya ialah kesadaran diri sendiri. Karena itulah pula manusia bersifat unik." ${ }^{3}$ Dalam kehidupan manusia terdapat dua proses yaitu pertumbuhan dan perkembangan di mana pertumbuhan adalah proses pematangan fisik sedangkan perkembangan adalah proses pematangan yang non-fisik.

Perkembangan juga berkaitan dengan belajar khususnya mengenai isi proses perkembangan: apa yang berkembang berkaitan dengan perilaku belajar. Di samping itu juga bagaimana sesuatu dipelajari, misalnya apakah melalui

${ }^{3}$ Noor Syam, Mohammad. Filsafat Pendidikan dan Dasar Filsafat Pendidikan Pancasila, Cet. IV; Surabaya: Usaha Nasional, 1988, 156. 
memorisasi (menghafalkan) atau mengerti hubungan, ikut menentukan perkembangan (Knores, 1985). Dengan demikian perkembangan dapat diartikan sebagai proses kekal dan tetap yang menuju ke arah suatu organisasi pada tingkat integrasi yang lebih tinggi, berdasarkan pertumbuhan, pemasakan dan belajar. ${ }^{4}$ Perkembangan dapat pula dikatakan sebuah proses diferensiasi dan bukan sebagai proses asosiasi dan kombinasi dari unsur-unsur yang lebih rendah.

Aristoteles (384-322 S.M.) membagi masa perkembangan selama 21 tahun dalam 3 septenia ( 3 periode kali 7 tahun), yang dibatasi oleh 2 gejala alamiah yang penting; yaitu (1)pergantian gigi dan (2) munculnya gejalagejala pubertas. Hal ini didasarkan pada paralelitas perkembangan jasmaniah dengan perkembangan jiwa anak. Perkembangan tersebut adalah sebagai berikut: 0-7 tahun, disebut sebagai masa anak kecil, masa bermain. 7-14 tahun, masa anak-anak, masa belajar, atau masa sekolah rendah. 1421 tahun, masa remaja atau pubertas, masa peralihan dari anak menjadi orang dewasa.

Perkembangan anak tidak berlangsung secara mekanis-otomatis. Sebab perkembangan tersebut sangat bergantung pada beberapa faktor secara simultan. Yaitu:

1. Faktor herediter (warisan sejak lahir, bawaan),

2. Faktor lingkungan yang menguntungkan atau yang merugikan,

3. Kematangan fungsi-fungsi organis dan fungsi-fungsi psikis, dan

4. Aktivitas anak sebagai subjek bebas yang berkemauan, kemampuan seleksi, bisa menolak atau menyetujui, punya emosi, serta usaha membangun diri sendiri. ${ }^{6}$

Setiap anak dapat berkembang dengan baik apabila didukung oleh foktorfaktor di atas. Hal tersebut dapat terealisasikan dengan adanya peran serta orangorang terdekat di sekeliling anak seperti keluarga. Bagi anak, orang tua merupakan tempat pelindung yang paling aman dan nyaman. Setiap orang tua pasti menginginkan yang terbaik untuk anaknya baik bagi pertumbuhan maupun

\footnotetext{
${ }^{4}$ F.J. Monks, A.M.P. Knoers dan Siti Rahayu Haditono, Psikologi Perkembangan (Cet. XIIII; Yogyakarta: Gajah Mada University Press, 2002), 2.

${ }^{5}$ Kartini Kartono, Psikologi Anak (Psikologi Perkembangan) (Cet. V; Bandung: Maju Mundur, 1995), 28.

${ }^{6}$ Ibid., 21.
} 
186 | MUSAWA, Vol. 12 No.2 Desember 2020 : 181-206

perkembangan juga dalam belajar sang anak, maka dari itu orang tua akan melakukan apa saja demi anak yang dicintainya. Sudah seharusnya seperti itu karena orang tua memiliki tanggung jawab penuh terhadap anak-anaknya yang merupakan amanah dari Allah yang harus dipenuhi kebutuhannya demi kelangsungan hidup anak tersebut. Ahmad Tafsir yaitu: "Tanggung jawab itu disebabkan sekurang-kurangnya oleh dua hal: pertama karena kodrat, yaitu karena orang tua ditakdirkan menjadi orang tua anak, dan karena itu ia ditakdirkan pula bertanggung jawab mendidik anaknya; kedua karena kepentingan kedua orang tua, yaitu orang tua berkepentingan terhadap kemajuan perkembangan anaknya, sukses anaknya adalah sukses orang tua juga." ${ }^{77}$ Hal ini sejalan dengan Firman Allah dalam Q.S. At-Tahrim (66):6.

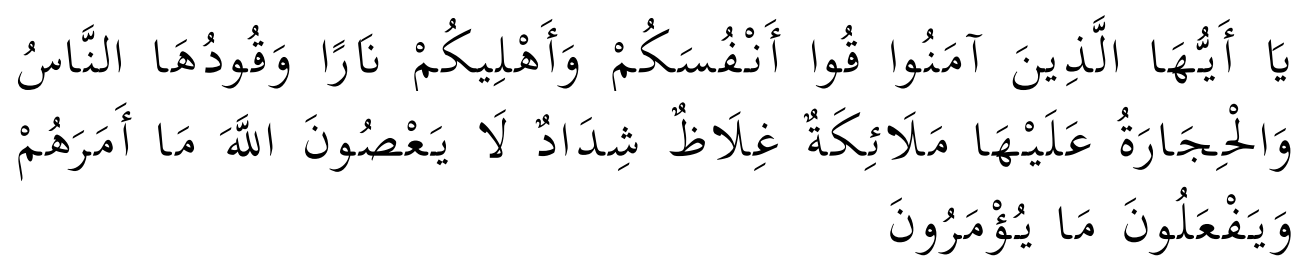

Terjemahnya: "Hai orang-orang yang beriman, peliharalah dirimu dan keluargamu dari api neraka yang bahan bakarnya adalah manusia dan batu; penjaganya malaikat-malaikat yang kasar, keras, dan tidak mendurhakai Allah terhadap apa yang diperintahkan-Nya kepada mereka dan selalu mengerjakan apa yang diperintahkan."8 (Q.S. At-Tahrim (66):6)

Ayat di atas menjelaskan bahwa, Allah memerintahkan manusia untuk menjaga diri beserta keluarga. Salah satu cara menjaga diri dan keluarga yakni memelihara anak serta memberikannya pendidikan. Namun, orang tua juga banyak yang meninggalkan anak-anaknya yang dikarenakan berbagai macam alasan tetapi mereka tidak memikirkan bagaimana dan seperti apa anak-anak tersebut bila ditinggalkan kedua orang tuanya. "Keberadaan keluarga bagi anak memiliki peranan penting seperti sebagai pelindung, dimana diperolehnya ketentraman dan ketertiban, sebagai unit sosial ekonomis yang secara materil memenuhi kebutuhan, sebagai tempat menumbuhkan dasar-dasar bagi kaidah-

\footnotetext{
${ }^{7}$ Ahmad Tafsir, Ilmu Pendidikan dalam Perspektif Islam (Cet. I; Bandung: Remaja Rosdakarya, 1992), 74.

${ }^{8}$ Departemen Agama Republik Indonesia, Al-Qur'an dan Terjemahannya (Jakarta: CV. Atlas, 2000), 951.
} 
kaidah pergaulan hidup, sebagai wadah dimana anak mengalami proses sosialisasi awal yakni proses dimana anak mempelajari dan mematuhi kaidah-kaidah dan nilai-nilai yang berlaku dalam masyarakat. ${ }^{9}$ Orang tua seharusnya menyayangi dan melindungi anak-anaknya bukan malah meninggalkan anak yang tidak mengerti apa-apa. Keegoisan dan kepentingan sendirilah yang biasanya memicu kejadian-kejadian seperti menelantarkan anak kerap terjadi.

Kondisi seperti ini sangat disayangkan, padahal Allah telah mengatur setiap takdir manusia dengan sebaik-baiknya termasuk lahirnya seorang anak yang merupakan amanah, rezeki dan cobaan yang harus dijalankan dengan kesabaran dan keikhlasan. Ini merupakan salah satu contoh kondisi sosial yang tidak baik. Kondisi sosial adalah suatu keadaan yang terjadi pada masyarakat atau seseorang dalam kehidupannya. Setiap orang memiliki latar belakang atau kondisi sosial yang berbeda-beda, ada yang menyenangkan dan ada pula justru kebalikannya. "Sekalipun pengaruh lingkungan tidak bersifat memaksa, namun tidak dapat diingkari bahwa peranan lingkungan cukup besar dalam perkembangan individu." 10 Kondisis sosial mempengaruhi perkembangan manusia terutama berdampak pada jiwanya.

Karena sifatnya yang abstrak, maka kita tidak dapat mengetahui jiwa secara wajar, melainkan kita hanya dapat mengenal gejalanya saja. Jiwa adalah sesuatu yang tidak tampak, tidak dapat dilihat oleh alat diri kita. Demikian pula hakekat jiwa, tak seorangpun yang dapat mengetahuinya. Manusia dapat mengetahui jiwa seseorang hanya dengan tingkah lakunya. Jadi tingkah laku itulah orang dapat mengetahui jiwa seseorang. Jadi tingkah laku itu merupakan kenyataan jiwa yang dapat kita hayati dari luar.

Tingkah laku anak dalam kehidupan sosialnya juga merupakan hal yang tidak bisa diacuhkan begitu saja, karena tingkah laku merupakan cerminan dari dalam jiwa anak. Jiwa merupakan sesuatu yang sensitif bagi manusia khususnya bagi anak-anak terlebih dalam kehidupannya terjadi peristiwa-peristiwa yang tidak menyenangkan, ini dikarenakan manusia mulai hidup sebagai makhluk yang kecil dan lemah. Apapun yang terjadi terhadap manusia, sepanjang hidupnya ini

\footnotetext{
${ }^{9}$ Soekanto Soerjono. 2004. Sosiologi Keluarga: Tentang Ikhwal Keluarga, Remaja Dan Anak (Jakarta: Raja grafindo persada), 13.

${ }^{10}$ Abu Ahmadi, Paikologi Umum (Cet. III; Jakarta: Rineka Cipta, 2003), 201.

${ }^{11}$ Ibid., 2.
} 
188 | MUSAWA, Vol. 12 No.2 Desember 2020 : 181-206

terus muncul ketika menghadapi sesuatu hal baru dan belum dikenal yang harus dijalaninya. Hal tersebut justru menjadi sebab semua perbaikan dalam tingkah laku manusia. Artinya, setiap apapun yang terjadi dalam kehidupan anak, mereka akan selalu mengingatnya dalam waktu yang lama dan mungkin permanen dalam memori atau ingatannya baik itu peristiwa yang menyenangkan maupun tidak. Pada dasarnya untuk mengetahui jiwa anak melalui tingkah lakunya ada beberapa unsur yang dikemukakan oleh Kartini Kartono yaitu sebagai berikut: "mengamati, menuliskan, mengklasifikasikan dan mengadakan sestematisasi, menjelaskan dan verstehen. $^{12,}$

Mengamati adalah suatu pengamatan secara langsung yang dilakukan dengan sengaja untuk mendapatkan apa yang diinginkan. Seperti halnya dalam mengetahui perkembangan jiwa anak melalui tingkah lakunya, pengamatan ini menjadi salah satu cara yang paling efektif dalam mempelajari serta dapat memprediksikan bagaimana perkembangan jiwa anak tersebut. pengamatan perlu dilakuakan dengan cara sistematis agar langkah-lakahnya lebih terarah untuk sampai pada kesimpulan akhir. Adapun menuliskan adalah sebuah kegiatan yang menuangkan gagasan, pikiran dan perasaan seseorang yang diungkapkan ke dalam bahasa tulisan. Menulis juga merupakan sebagai suatu kegiatan untuk menyatakan pikiran atau sebuah ungkapan perasaan dalam bentuk tertulis yang diharapkan dapat dipahami oleh pembaca dan berfungsi sebagai alat komunikasi secara tidak langsung. Menulis di sini dapat diartikan sebagai suatu pendeskripsian dan suatu penyusunan secara sistematis tentang suatu hal yang menjadi perhatian yakni tingkah laku anak dalam mengetahui perkembangan jiwanya.

Dalam kehidupan sehari-hari dapat dilihat, bagaimana manusia baik secara orang-orangnya maupun secara kelompok, dan manusia dalam hubungannya dengan kelompoknya bertingkah laku. Seorang guru misalnya berhasil membangkitkan motivasi belajar murid-muridnya.

Para sosiolog, beranggapan bahwa masyarakat sendiri memiliki peran penting dalam pembentukan moral yang berkaitan dengan tingkah laku. Salah satunya W.G. Summer, yang merupakan seorang sosiolog, berpendapat bahwa:

\footnotetext{
${ }^{12}$ Ibid., 53.

${ }^{13}$ Ibid., 56.
} 
Tingkah laku manusia yang terkendali disebabkan oleh adanya kontrol dari masyarakat itu sendiri. Masyarakat yang mempunyai sanksi-sanksi tersendiri untuk pelanggaran-pelanggarannya, kontrol masyarakat itu adalah sebagai berikut:

1. Flokways, yaitu tingkah laku yang lazim, misalnya makan dengan tangan kanan, bekerja atau bersekolah, dan sebagainya.

2. Mores, yaitu tingkah laku yang sebaiknya dilakukan, misalnya: mengucapkan terima kasih atas jasa seseorang, atau memberikan salam pada waktu berjumpa.

3. Law (hukum), yaitu tingkah laku yang harus dilakukan atau dihindari, misalnya tidak boleh mencuri, harus membayar utang, dan lain-lain. ${ }^{14}$

Peranan masyarakat beserta aturan-aturannya juga berlaku bagi anak yatim, yatim piatu dan terlantar untuk mengarahkan mereka menuju pribadi yang lebih baik walaupun dengan kondisi sosial yang dimilikinya. Selain itu, dengan adanya peran masyarakat ini bisa menjadi motivasi. Manusia dimotivasi oleh adanya dorongan dari dalam dirinya sendiri dan dari lingkungan sekitarnya telah termasuk di dalamnya masyarakat. Melihat kondisi sosial atau kerap disebut latar belakang sosial ini menjadi suatu pembicaraan yang tidak terlepas dari kehidupan yang biasanya menjadi motivasi yang sangat menunjang. Kedua hal ini saling membantu dalam proses kehidupan serta dalam hal pencapaian yang diinginkan oleh manusia. Pengertian motifasi menurut Slameto dalam bukunya "Belajar dan Faktor-Faktor yang Mempengaruhiya" yaitu: "Proses yang menentukan tingkat kegiatan, intensitas, konsistensi, serta arah umum dari tingkah laku manusia yang berhubugan dengan minat, konsep diri, sikap dan sebagainya." ${ }^{15}$ Proses itulah yang mengarahkan manusia kepada perubahan yang bersifat positif dimana tergantung bagaimana cara manusia itu mengambil sikap dalam kehidupannya.

Motivasi juga sangat membantu dalam belajar, misalnya anak yang tidak memiliki orang tua atau kerabat sangat terbantu oleh motivasi-motivasi yang diberikan serta memunculkan rasa kepercayaan pada kemampuan dirinya, karena tanpa adanya dorongan anak akan merasa enggan dalam melakukan sesuatu yang menjadi keharusan bagianya. Hal ini disebabkan kondisi sosial mereka yang tidak menyenangkan membawa kebanyakan dari meraka menjadi kepribadian yang

\footnotetext{
${ }^{14}$ Sarlito Wirawan Sarwono, Berkenalan dengan Aliran dan Tokoh-Tokoh Psikologi (Jakarta: Bulan Bintang, 1986), 23.

${ }^{15}$ Slameto, Belajar dan Faktor-Faktor yang Mempengaruhiya (Cet. IV; Jakarta: Rineka Cipta, 2003), 170.
} 
190 | MUSAWA, Vol. 12 No.2 Desember 2020 : 181-206

lemah, pasif, apatis, menarik diri, mudah putus asa dan penuh dengan ketakutan dan kecemasan dalam diri dan pikirannya.

Manusia dimotivasi oleh adanya dorongan utama, Hal itu tidak berarti rendah diri terhadap orang lain dalam pengertian yang umum, meski ada unsur membandingkan kemampuan diri dengan kemampuan orang lain yang lebih matang dan berpengalaman. Misalnya manusia lebih lemah akan berjuang untuk menjadi lebih kuat.

Dalam upaya untuk melakukan kompensasi, anak-anak memperoleh berbagai macam tingkah laku. Tingkah laku ini menjadi bagian dari gaya hidup (the style of life). Gaya hidup dipelajari dari interaksi sosial yang terjadi pada tahun-tahun awal kehidupan. Gaya hidup dan interksi sosial juga merupaka bagian dari proses perkembangan anak yang tidak terlepas dari bimbingan dan arahan yang diberikan. Apabila anak-anak yang memiliki orang tua, maka orang tuanya lah yang melakukan pembimbingan itu tetapi berbeda dengan anak-anak yang berada di panti asuhan yang tidak memiliki orang tua, mereka mendapatkan bimbingan dari pengasuh yang merawat mereka.

Menurut aliran psikolog, pengaruh sosial yang utama ketika masa kanakkanak ada beberapa keadaan seperti ditolak atau diabaikan cenderung merasa dirinya tidak berharga sehingga mempengaruhi interksi sosial terhadap lingkungannya sekaligus mempengaruhi perkembangan dan kepribadian mereka. Contohnya anak yang diabaikan merasa tidak mampu menghadapi tuntutan hidup, karena itu mereka tumbuh dengan rasa ketidakpercayaan. Hal ini sejalan dengan pendapat Kartini Kartono dalam bukunya "Psikologi Anak" yaitu: Antara lain bayi ditinggalkan ibu, ayah atau kedua orang tuanya. Sebab inilah anak-anak dititipkan dalam suatu Institusionalia (rumah sakit, rumah yatim piatu, yayasan perawatan bayi, dan lain-lain), sehingga mereka kurang sekali mendapatkan perawatan jasmaniah dan cinta kasih. Anak-anak tersebut mengalami innanite psikis (kehampaan psikis, kering dari perasaan), sehingga mengakibatkan retardasi/kelambatan petumbuhan pada semua fungsi jasmaniah. Juga ada 
hambatan fungsi rokhaniah; terutama sekali pada perkembangan intelegensi dan emosi. $^{16}$

Akan tetapi, keadaan tersebut bisa teratasi dengan adanya perhatian yang diberikan kepada mereka yang membutuhkan. Bukan hanya material juga kasih sayang dan dukungan penuh kepada anak-anak yatim menjadi suatu keharusan bagi kita semua. Dengan demikian hubungan anak dengan orang tua bukan satusatunya sarana perkembangan anak serta pembentuk kepribadian. Masyarakat sendiri punya peran penting dalam pembetukan kepribadian khususnya pada anakanak yatim, karena siapa lagi yang memperhatikan mereka kalau bukan masyarakat yang ada di sekitarnya yang memang menjadi tanggung jawab dan sebagai bentuk kemanusiaan kita.

Sebagai makhluk sosial, manusia tidak bisa hidup sendiri, tumbuh dan berkembang sendiri tanpa adanya manusia lain. Karena itulah kepribadian manusia terbentuk dari lingkungan sosial dan interaksi yang unik, bukan oleh usaha-usaha mencapai kepuasan biologis.

\section{B. Faktor -faktor Sosial dalam Mempengaruhi Motivasi Belajar Anak Yatim Piatu}

Manusia dalam perkembangannya dipengaruhi oleh faktor-faktor pendukung maupun penghambat. Faktor-faktor tersebut bukan hanya satu atau dua tetapi banyak faktor baik dari dalam (internal) maupun dari luar (eksternal). Manusia tidak terlepas dari kondisi sosial dimana merupakan sesuatu yang tidak terpisahkan dari kehidupan manusia itu sendiri. Kondisi sosial ini bisa baik atau bahkan sebaliknya, karena itulah kondisi sosial merupakan salah satu faktor yang besar pengaruhnya terhadap kehidupan manusia. Untuk itu, faktor kondisi sosial yang mempengaruhi proses belajar hendaknya diperhatikan. Sejalan dengan ungkapan Rahmat Mulyana, sebagai berikut:

Ketika pembicaraan kemampuan manusia, pemikiran klasik dalam psikologi sampai pada pertanyaan tentang manakah yang paling berpengaruh pada proses belajar seseorang, adalah faktor bawaan atau faktor lingkungan maka faktor tersebut disebut dengan faktor nature dan aliran empirisme, yang

\footnotetext{
${ }^{16}$ Kartono, Psikologi Anak (Psikologi Perkembangan), 20.
} 
192 | MUSAWA, Vol. 12 No.2 Desember 2020 : 181-206

menempatkan faktor lingkungan (nature) sebagai faktor yang paling berpengaruh terhadap perkembangan diri individu.

Pada dasarnya anak yatim, yatim piatu dan terlantar sama dengan anakanak pada umumnya tetapi ada perbedaan yang sangat mendasar yakni dari segi psikologisnya yang biasa disebut psikis anak. Perbedaan kondisi sosial inilah menjadi faktor yang paling berpengaruh terhadap anak-anak yatim, yatim piatu dan terlantar. Tidak sedikit dampak negatif yang diberikan oleh faktor kondisi sosial ini terhadap belajar anak-anak tersebut. Hal ini dikarenakan kondisi sosial merupakan sesuatu yang sangat berkaitan dengan kehidupan. Belajar dapat diartikan penguatan respon, mengubah pengetahuan peserta didik dalam bidang tertentu, sifat khusus, dan karakternya.

Kondisi sosial yang kurang baik memang menjadi faktor penghambat bagi belajar anak bukan hanya itu, anak juga akan terhambat dalam perkembangannya terutama mental anak itu sendiri yang bisa dikatakan sangat membutuhkan perhatian lebih. Anak-anak yatim, yatim piatu dan terlantar yang masih kecil belum mengerti dan belum memahami kehidupan tetapi bagi mereka yang telah beranjak dewasa tentu sudah mulai berpikir mengenai kehidupan dan apa yang terjadi dalam hidupnya serta memikirkan kehidupan selanjutnya. Saat-saat seperti inilah mereka mencapai titik penurunan minat belajar, karena itu butuh kerja keras untuk mereka menghadapi kenyataan yang ada namun perlu adanya bimbingan dan arahan dari setiap lapisan masyarakat yang tidak terlepas pula pemerintah di dalamnya. Faktor penghambat dari kondisi sosial juga terlihat dengan adanya pendiskriminasian.

Diskriminasi (Discrimination) adalah sebuah sikap, perilaku, dan tindakan yang mencerminkan ketidakadilan yang dilakukan baik secara individu maupun kelompok. Diskriminasi juga dapat dikatakan suatu tindakan atau perbuatan yang membeda-bedakan antara orang satu dengan lainnya yang disebabkan adanya suatu situasi dan kondisi individu atau kelompok. Diskriminasi sering terjadi pada orang-orang yang dalam kondisi sosial atau kejadian-kejadian dalam hidup orang

\footnotetext{
${ }^{17}$ Rahmat Mulyana, Mengartikulasi Pendidikan Nilai (Bandung: Alfabet, 2004), 45.
} 
tersebut. Seperti yang kerap terjadi pada anak-anak yatim, yatim piatu dan terlantar sering dipandang sebelah mata baik di masyarakat maupun di lingkungan sekolahnya. Diskriminasi harus ditiadakan karena pendeiskriminasian merupakan perilaku yang menyimpang dan memberi dampak buruk.

Selain menjadi faktor penghambat, kondisi sosial juaga menjadi faktor penunjang dalam belajar anak yatim, karena dengan kondisi sosial yang mereka miliki menjadi motivasi tersendiri bagi anak-anak tersebut apalagi bila didukung oleh interaksi sosial yang baik dilingkungannya. "Orang-orang tidak hanya berbeda dalam kemampuan untuk berbuat akan tetapi juga berbeda dalam kemauan untuk berbuat atau motivasi. ${ }^{18, "}$ terkadang orang membutuhkan sesuatu hal yang dapat membangkitkan dan meningkatkan motivasinya seperti adanya motif-motif yang diarahkan untuk berbuat. Sumardi Suryabrata berpendapat bahwa faktor yang mempengaruhi proses belajar mengajar adalah "faktor-faktor yang berasal dari luar diri pelajar, yaitu: faktor non sosial dan faktor sosial, faktor yang berasal dari dalam diri pelajar, yaitu: faktor psikologi dan faktor fisiologis." ${ }^{19}$ Moekijat dalam bukunya Dasar-Dasar Motivasi menjelaskan faktor motivasi intern dan ekstern sebagai berikut:

\section{Motivasi Intern}

Kebutuhan-kebutuhan dan keinginan-keinginan yang terdapat dalam seorang individu menambah motivasi intern-nya. Kekuatan-kekuatan ini mempengeruhinya dengan menentukan pikiran-pikirannya, yang selanjutnya membimbing perilakunya kedalam suatu situasi tertentu.

\section{Motivasi Ekstern}

Telah dijelaskan bahwa teori motivasi intern mempertimbangkan kekuatankekuatan yang terdapat dalam diri seorang individu kebutuhan-kebutuhan dan keinginan-keinginannya. Teori motivasi ekstern tidak meniadakan teori motivasi intern, akan tetapi menambahnya.

Dari penjelasan di atas menunjukkan bahwa motivasi intern atau internal merupakan motivasi yang berasal dari dalam diri manusia berupa minat, niat dan

\footnotetext{
${ }^{18}$ Moekijat, Dasar-Dasar Motivasi (Bandung: Pionir Jaya, 2002), 15.

${ }^{19}$ Sumardi Suryabrata, Psikologi Pendidikan (Jakarta: DEPDIKBUD, 1983), 192.

${ }^{20}$ Moekijat, Dasar-Dasar Motivasi, 9.

${ }^{21}$ Ibid., 11.
} 
194 | MUSA WA, Vol. 12 No.2 Desember 2020 : 181-206

semangat yang ada pada dirinya dan keinginan-keinginan yang ingin dicapai dalam hidup. Motivasi ini mendorong semangat yang kuat dari dalam diri manusia sehingga dengan motivasi internal manusia akan bekerja lebih keras lagi. Sama halnya anak-anak pada umumnya memiliki kedua orang tua, anak yatim yang dengan kekurangannya tersebut mereka memiliki harapan dan keinginankeinginan yang ingin dicapai dalam kehidupan. Faktor internal sendiri terbagi menjadi dua yaitu: (1) Pisiologis dan (2) Psikologis.

1. Pisiologis

Pisiologis adalah kondisi sesorang secara fisik dan dapat dilihat dengan panca indra seperti tubuh atau badan. Seperti kesehatan yang baik akan sangat membantu dalam proses dan hasil belajar.

Kondisi umum jasmani dan tonus (tangan otot) yang menandai tingkat kebugaran organ-organ tubuh dan sendi-sendinya, dapat mempengaruhi semangat dan intensitas siswa dalam mengikuti pelajaran. Kondisi organ tubuh yang lemah, apalagi jika disertai pusing-pusing kepala misalnya, dapat menurunkan kualitas rana cipta (kognitif) sehingga materi yang dipelajarinya pun kurang atau tidak berbekas. ${ }^{22}$

Anak yang sakit tidak dapat mengikuti pembelajaran dengan efisien. Sebab anak yang sakit tidak dapat berkonsentrasi pada saat proses pembelajaran berlangsung yang membuat anak tidak mudah dalam menerima pelajaran yang diberikan oleh pendidik dan akhirnya minat dan motivasi belajar anak menurun.

\section{Psikologis}

Psikologis adalah berkaitan dengan mental, jiwa yang tidak dapat dilihat oleh panca indra. Kondisi psikologis setiap orang berbeda-beda, perbedaan yang dimaksudkan adalah bukan dari jenisnya melainkan dari kadar atau takarannya.

Banyak faktor yang termasuk aspek psikologis yang dapat mempegaruhi kuantitas dan kualitas perolehan pembelajaran siswa. Namun, di antara faktor-faktor rohaniah siswa yang pada umumnya dipandang lebih esensial

\footnotetext{
${ }^{22}$ Muhibbin Syah, Psikologi Pendidikan dengan Pendekatan Baru (Cet. XII; Bandung: Remaja Rosdakarya, 2006), 132.
} 
itu adalah sebagai berikut: 1) tingkat kecerdasan/intelegensi siswa; 2) sikap siswa; 3) bakat siswa; 4) minat siswa; 5) motivasi siswa.

Psikologis merupakan hal yang paling sensitif karena mental atau jiwa seseorang sangat mempengaruhi pertumbuhan dan perkembangan seseorang. Oleh karena itu, faktor psikologis ini sangat membutuhkan perhatian yang tidak dapat diacuhkan begitu saja karena kan berdampak sangat besar bagi anak baik dari proses belajarnya hingga pertumbuhan dan perkembangan sang anak, termasuk diantaranya faktor-faktor rohaniah yang disebutkan Muhibbin Syah. Semua faktor yang ada saling mempegaruhi terhadap proses belajar.

Adapun motivasi eksternal yang telah dijelaskan pula di atas merupakan motivasi yang berasal dari luar diri manusia atau dari lingkungan sekitarnya seperti anak yatim, yatim piatu dan terlantar diberiakan motovasi-motivasi yang dapat meningkatkan semangat belajarnya dan menuntut ilmu. Mengingat anak yatim, yatim piatu dan terlantar merupakan anak yang tidak memiliki dan tidak mendapatkan kasih sayang orang tuanya maka anak-anak tersebut sangat membutuhkan motivasi dari lingkungannya atau orang-orang disekitarnya.

\section{Motivasi belajar Agama Islam bagi Anak Yatim Piatu dalam tinjauan Soaial}

Pada dasarnya ajaran Islam yang tertuang dalam al-Qur'an dan sunnah serta ijma' para ulama banyak mengajarkan tentang kehidupan yang terarah dan teratur. Teori dan konsep belajar yang digunakan saat ini bukan merupakan hal yang baru dalam perspektif Islam. Belajar telah ada paling tidak ketika Allah menciptakan manusia yang pertama yaitu Nabi Adam as. Unsur-unsur belajar dalam penciptaan alam serta makhluk-makhluk lainnya tidak terlepas dari sebuah proses. Contoh realisasi proses belajar seperti digambarkan oleh Allah dalam alOur'an mengenai kisah Lukman. Tidak heran jika Lukman diabadikan namanya menjadi salah satu nama surat dalam kitab suci al-Qur'an pada surat ke 31. Kisah hidup Lukman memiliki banyak keistimewaan yang dapat diambil ibrah atau pelajaran yang sangat berharga dari kehidupannya. Dalam menjalankan kehidupannya, Lukman yang diberi nikmat dan ilmu pengetahuan, selalu

\footnotetext{
${ }^{23}$ Ibid., 133.
} 
196 | MUSAWA, Vol. 12 No.2 Desember 2020 : 181-206

bersyukur kepada-Nya atas nikmat yang diberikan atas dirinya. Tidak hanya itu, kisah Lukman dalam medidik anak-anaknya salah satunya berupa nasihat-nasihat. Ini adalah sebagai isyarat dari Allah supaya setiap ibu dan bapak melaksanakan pula terhadap anak-anak mereka sebagaimana yang telah dilakukan oleh Lukman.

Setiap individu anak dan orang dewasa itu selalu mempunyai kebutuhankebutuhan tertentu (yang bersifat vital biologis, dan human/sosial-kultural) untuk mempertahankan hidupnya, kebutuhan-kebutuhan tersebut menuntut agar dipenuhi, sehingga tidak terjadi ketegangan batin, konflik-konflik batin dan frustasi. Sehubung dengan ini setiap individu senantiasa berusaha menyingkirkan semua rintangan yang menghambat pelaksanaan pemenuhan kebutuhan tadi. ${ }^{24}$

Setiap manusia memiliki kebutuhan termasuk mislanya jika terjadi keterbatasan yang dimiliki anak seperti yatim piatu dan terlantar pada umumnya, tidak lantas secara keseluruhan membuatnya menjadi anak yang selalu bergantung pada orang lain, semaksimal mungkin mereka akan berjuang. Hidup tanpa orang tua bukan halangan bagi seorang anak yatim, yatim piatu dan terlantar. Ketiadaan kedua orang tuanya tidak lantas menjadikannya anak yang lemah serta mudah putus asa. Sebaliknya, ini justru menjadi tumpuan semangat agar senantiasa memberikan yang terbaik untuk orang-orang di sekitarnya. Memang sulit melangkah tanpa adanya kedua orang tua tetapi inilah kenyataan yang mau tidak mau anak yatim, yatim piatu dan terlatar harus menerima, kondisi semacam ini juga secara spontan menjadi penyemangat bagi mereka.

Dalam harapan pasti ada jalan. Ketika keinginan atau niat hati yang tulus untuk berbuat dengan tulus dan ikhlas maka Allah akan selalu membantu dan memudahkan dalam terlaksananya perbuatan baik tersebut. Allah berfirman dalam Q.S. an-Maa'uun (107): 1-3.

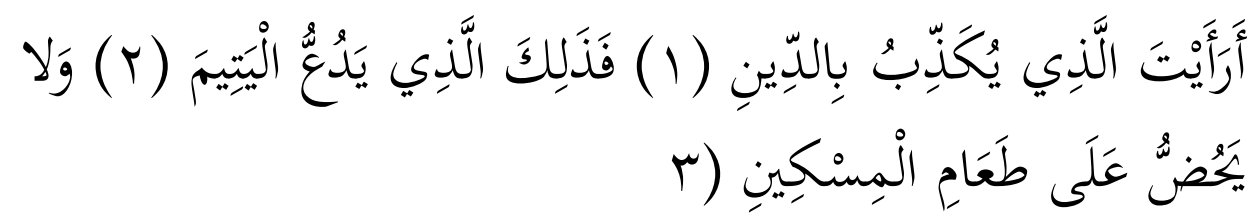

\footnotetext{
${ }^{24}$ Kartono, Psikologi Anak (Psikologi Perkembangan), 47.
} 
Terjemahanya: "Tahukah kamu orang yang mendustakan agama? Itulah orang yang menghardik anak yatim. Dan tidak menganjurkan memberi makan orang miskin."25 (Q.S Al-Maa'uun (107) 1-3)

Dalam Al-Qur'an Allah telah menjelaskan bahwa anak yatim, yatim piatu dan terlantar harus diberikan perlindungan, kasih sayang, dan bimbingan serta dukungan berupa motivasi-motivasi yang membangun. Selain itu ayat di atas juga menjelaskan bahwa umat Islam diharuskan untuk membantu orang yang tidak mampu atau kaum duafa.

Dukungan sosial yang diterima seseorang dalam lingkungannya berupa dorongan semangat, perhatian, penghargaan, bantuan maupun kasih sayang membuatnya akan memiliki pandangan positif terhadap diri dan lingkungannya. Pandangan positif terhadap diri dan lingkungannya dibutuhkan agar individu mampu menerima kehidupan yang dihadapi dan mempunyai sikap pendirian dan pandangan hidup yang jelas, sehingga mampu hidup di tengah-tengah masyarakat luas secara harmonis. Jika individu merasa didukung oleh lingkungan, segala sesuatu dapat menjadi lebih mudah pada saat mengalami kejadian-kejadian yang menegangkan (Smet, 1994). ${ }^{26}$

Selain adanya perhatian yang diberikan di tempat panti asuhan dan masyarakat, lingkungan sekolah juga merupakan tempat di mana anak akan mendapatkan bimbingan, pengarahan yang tentu berbeda dari lingkungan tempat tinggalnya dan masyarakat. Sekolah merupakan tempat pengembangan pengetahuan, sikap dan keterampilan dengan pembelajaran yang ada di sekolah, anak akan didik dengan sistem pembelajaran yang telah disusun secara sistematis dan terencana. Denagan melihat nilai-nilai perubahan kondisi sosial yang tercantum dalam fungsi pendidikan nasional, dapat dipahami bahwa pendidikan nasional memiliki muatan nilai sebagai pendorong terjadi perubahan sosial, khususnya pengembangan potensi atau kompetensi peserta didik sebagai salah satu bagian dari masyarakat.

\footnotetext{
${ }^{25}$ Departemen Agama Republik Indonesia, Al-Qur'an dan Terjemahannya (Jakarta: CV. Atlas, 2000),

${ }^{26}$ D Sari, PDF, http://repository.uin-suska.ac.id/6201/2/BAB\%20I.pdf (27 Mei 2018), 5.
} 
198 | MUSA WA, Vol. 12 No.2 Desember 2020 : 181-206

Dalam kemajuan teknologi dan ilmu pengetahuan, sekolah memegang peranan penting sebagai "agent of change" untuk membawa perubahan sesuai dengan harapan masyarakat. Sekolah biasanya terlampau memusatkan perhatian kepada pendidikan akademis, salah satu aspek yang perlu mendapat perhatian adalah memupuk hubungan sosial di kalangan peserta didik. Program pendidikan peserta didik, antara golongan ini bergantung pada struktur sosial peserta didik dengan pembelajaran yang baik. Pembelajaran diartikan sebagai kegiatan belajar mengajar konvensional dimana pendidik dan peserta didik langsung berinteraksi. Pembelajaran memiliki tujuan untuk meperoleh pengetahuan yakni kognitif dan konstruksi pengetahuan. Kognitif adalah proses berpikir yang terjadi di balik tindakan dan menerima, mengelolah serta menyimpan informasi. Sedangkan konstruksi pengetahuan adalah aktivitas sosial dan kultural peserta didik mengkonstruksi makna melalui pengalamannya. "Dalam perkembangan itu, kognitif mengikuti prinsip adaptif yaitu penyesuaian terhadap lingkungan yang bersangkut paut dengan tujuan dan perjuangan hidup." ${ }^{27}$ Hal ini dikarenakan rana kognitif merupakan rana berpikir sesorang yang perlu dipikirkan serta dianalisis.

Di sekolah anak-anak yatim, yatim piatu dan terlantar dapat dikembangkan dari segi pengetahuan, sikap, kreatifitas maupun sosialnya. Selain itu, mereka juga akan lebih leluasa untuk mengeksplorasikan kemampuan yang mereka miliki sama seperti anak-anak lainnya. Anak yatim, yatim piatu dan terlantar tidak boleh dibeda-bedakan atau adanya pendiskriminasian dengan peserta didik yang keseluruhan memiliki kedua orang tua. Olehnya, pendidik memegang peran utama dalam hal ini terutama pada saat proses belajar mengajar. Keberadaan pendidik memiliki peranan dalam mewujudkan peserta didik yang berkualitas agar siap dalam menghadapi perubahan sosial yang dihadapkan padanya.

Pendidik adalah tenaga pendidikan di sebuah instansi lembaga pendidikan yang bersifat resmi juga merupakan agen perubahan (agent of change) yang membawa sebuah inovasi dalam pendidikan terutama dalam proses pembelajaran. Tampak jelas bahwa pendidik adalah salah satu penentu keberhasilan belajar

${ }^{27}$ Singgih D Gunarsa, Dasar-Dasar dan Teori Perkembangan Anak (Jakarta: BPK, Gunung Mulya, 1982), 141. 
peserta didik, baik berupa hasil belajar, motivasi dalam belajar, saran dan lain sebagainya.

Pendidik harus memiliki kopetensi kepribadian yang baik yakni pendidik sebagai pembangun generasi baru harus memiliki tingkah laku yang bermoral tinggi demi masa depan agama, bangsa dan negara karena pendidik merupakan teladan bagi peserta didiknya yang merupakan generasi penerus agama dan bangsa. Selain itu, pendidik juga harus memiliki kompetensi profesionalisme dalam tugasnya. Tugas seorang pendidik bukan hanya mengajar tetapi juga mendidik peserta didiknya kearah yang lebih baik yang sesuai dengan harapan agama, bangsa dan negara. Tugas pendidik dalam mengajar, membimbing dan mendidik seluruh peserta didiknya dan tidak terkecuali anak-anak yatim, yatim piatu dan terlantar perlu dilakukan dengan sepenuh hati dan sungguh-sungguh. Kompetensi adalah kemampuan bersikap, berpikir dan bertindak secara konsisten sebagai perwujudan dari tanggung jawab yang diberikan pada pendidik. Hal ini sesuai dengan sikap seorang pendidik sebagai fasilitator yang diidentifikasikan Rogers (dalam Mulyasa, 2002) sebagai berikut:

1. Tidak berlebihan mempertahankan pendapat dan keyakinannya, atau kurang terbuka;

2. Dapat lebih mendengarkan peserta didik, terutama tentang aspirasi dan perasaannya;

3. Mau dan mampu menerima ide peserta didik yang inovatif, dan kreatif, bahkan yang sulit sekalipun;

4. Lebih meningkatkan perhatiannya terhadap hubungan dengan peserta didik seperti halnya terhadap bahan pembelajaran;

5. Dapat menerima balikan (feedback), baik yang sifatnya positif maupun negatif, dan menerimanya sebagai pandangan yang konstruktif terhadap diri sendiri dan perilakunya;

6. Toleransi terhadap kesalahan yang diperbuat peserta didik selama proses pembelajaran; dan 
200 | MUSAWA, Vol. 12 No.2 Desember 2020 : 181-206

7. Menghargai prestasi peserta didik, meskipun biasanya mereka sudah tahu prestasi yang dicapainya. ${ }^{28}$

Hubungan pendidik dan peserta didik perlu dibangun dalam proses belajar mengajar karena ada kebutuhan yang ingin dipenuhi dari keduanya. "Kegiatan pendidikan yang melibatkan guru dan siswa yang di dalamnya mutu pengalaman belajar ditentukan oleh watak hubungan antar keduanya". ${ }^{29}$ Keterlibatan pendidik terutama pendidik mata pelajaran Pendidikan Agama Islam memiliki tugas yang sangat penting yakni menanamkan nilai-nilai religi sesuai dengan al-Qur'an dan sunnah Rasul terhadap setiap peserta didik serta melakukan pendekatanpendekatan yang sesuai dengan karakter dan kepribadian peserta didik contohnya, peserta didik yang memiliki kondisi sosial yang dimiliki anak-anak yatim, yatim piatu dan terlantar, pendidik melakukan pendekatan dengan kasih sayang dan perhatian penuh pada diri anak tersebut misalnya memberikan dorongan-dorongan atau motivasi dalam belajarnya, memberi penghargaan pada kerja kerasnya dan pendidik dapat menjadi teman bagi mereka. Pendidik manjadi seorang teman bagi peserta didiknya, bukan berarti peserta didik seperti halnya berteman dengan sebayanya akan tetapi teman dalam artian tidak menutup diri atau saling terbuka antara pendidik dan peserta didiknya dengan masih ada batasan-batasan antara pendidik dan peserta didik.

Apabila pendekatan-pendekatan yang dilakukan terhadap anak yatim, yatim piatu dan terlantar tersebut efektif dan berkesinambungan maka dengan sendirinya anak-anak tersebut menjadi lebih terbuka serta tidak enggan untuk membagi cerita bahagia maupun kesedihannya. Sehingga anak-anak yatim, yatim piatu dan terlantar dapat dengan mudah ditingkatkan motivasi belajar dari kondisi sosial yang mereka miliki. Hasil belajar pada umumnya meningkat jika motivasi untuk belajar bertambah, karena apabila motivasi meningkat maka dorongan untuk berbuat juga meningkat.

\footnotetext{
${ }^{28}$ E. Mulyasa, Pengembangan dan Implementasi Kurikulum 2013 (Cet. III; Bandung: Remaja Rosdakarya, 2013), 42.

${ }^{29}$ Sahabuddin, Pendidikan Non Formal (Suatu Pengantar dalam Pemahaman Konsep dan Prinsip-Prinsip Pengembangan) (Ujung Pandang: IKIP, 1983), 93.
} 
Suatu hal yang tidak boleh dilupakan oleh guru ialah bahwa pengajaran keimanan itu banyak berhubungan dengan aspek kejiwaan dan perasaan. Nilai pembentukan yang diutamakan dalam mengajar ialah keaktifan fungsifungsi jiwa (pembentukan fungsional). Pengajaran lebih banyak bersifat efektif. ${ }^{30}$

Memang bukanlah kewajiban sekolah atau pendidikan semata-mata membimbing pengertian anak-anak untuk memahami realita dunia yang nyata ini. Kewajiban sekolah juga untuk membina kesadaran tentang kebenaran yang berpangkal atas realita itu tadi. Ini berarti realita itu sebagai tahap pertama, sebagai stimulus untuk menyelami kebenaran. Anak-anak secara sistematis wajib dibina potensi berpikir kritis untuk mengerti kebenaran itu. Mereka harus mampu mengerti perubahan-perubahan di dalam lingkungan hidupnya baik tentang adat istiadat, tentang tata sosial dan pola-pola masyarakat, maupun tentang nilai-nilai moral dan hukum. Daya pikir yang kritis akan sangat membantu pengertian tersebut. Kewajiban pendidikan malalui latar belakang ontologis ini ialah membina daya pikir yang tinggi dan kritis itu. ${ }^{31}$

Setiap pengalaman hidup harus dijadikan sebagai penyemangat dalam mengembangkan setiap potensi untuk kemajuan dalam hidup. Saat muncul sebuah kejadian-kejadian atau permasalahan-permasalahan seharusnya manusia bisa bangkit dari keterpurukan dan mencoba hal-hal baru yang bernilai positif dan memberikan manfaat bagi diri sendiri maupun orang lain yang dapat membawa pada sebuah inovasi dalam kehidupan. Sikap inilah yang diharapkan selalu ada dan dipertahankan oleh anak-anak yatim, yatim piatu dan terlantar seperti anakanak di yayasan panti asuhan Al-Ikhlas terlebih dalam belajarnya. Sesuai dari penjelasan tersebut Ahmad Tafsir mengatakan bahwa

Islam mengingatkan pemeluknya cerdas serta pandai. Itulah ciri akal yang berkembang secara sempurna. Cerdas ditandai oleh adanya kemampuan menyelesaikan masalah dengan cepat dan tepat, sedangkan pandai ditandai

\footnotetext{
${ }^{30}$ Zakiah Darajat, et.al, Metodik Khusus Pengajaran Agama Islam, edisi kedua (Cet. I; Jakarta: Bumi Aksara, 1995), 68

${ }^{31}$ Mohammad Noor Syam, Filsafat Pendidikan dan Dasar Filsafat Pendidikan Pancasila (Cet. IV; Surabaya: Usaha Nasional, 1988), 30.
} 
oleh banyak memiliki informasi. Salah satu ciri Muslim yang sempurna ialah cerdas serta pandai ${ }^{32}$

Maksudnya dari pernyataan Ahmad Tafsir di atas adalah sejak lahir setiap manusia memiliki potensi-potensi yang diberikan Allah salah satunya adalah potensi akal. Manusia harus menggunakan akal yang telah diberikan Allah untuk menyelesaikan setiap masalah yang ada dengan cara yang baik serta mengambil setiap hikmah dibalik permasalahan tersebut. Potensi anak-anak yatim, piatu, yatim piatu, dan terlantar juga perlu diarahkan dan dibimbing agar pertumbuhan dan perkembangannya baik dari segi intelegensi, sosial dan agama Adapun perkembangan aspek-aspek kognitif meliputi beberapa hal sebagai berikut:

1. Kematangan, yang merupakan susunan syarat sehingga misalnya fungsifngsi indra menjadi lebih sempurna.

2. Pengalaman, yaitu hubugan timbal balik dengan lingkungannya.

3. Transmisi sosial, yaitu hubungan timbal balik dengan lingkungan sosial, antara lain melalui pengasuhan dan pendidikan dari orang lain.

4. Ekulibrasi, yaitu sistem pengaturan dalam diri anak itu sendiri yang mampu mempertahankan keseimbangan dan menyesuaikan diri terhadap lingkungannya. ${ }^{33}$

Dari aspek-aspek kognitif yang disebutkan di atas, keseluruhan mengarah kepada perkembangan anak secara menyeluruh baik dari psiologis maupun psikologisnya. Bukan hanya potensi akal saja yang harus dikembangkan tetapi juga semua potensi-potensi yang ada.

Memberikan pendidikan agama sangat efisien dalam mendidik dan membimbing anak serta menjadikan anak dengan kondisi sosialnya menjadi motivasi apabila didukung oleh lingkungan luar yang baik. Pendidikan agama sebagai kontrol sosial juga membangun karakter anak untuk memiliki moral dan sikap (attitude) yang baik. Sikap (attitude), sebagai salah satu bentuk respon nyata. Dengan pemahaman pendidikan agama Islam ditanamkan pada anak-anak terlebih

Tafsir, Ilmu Pendidikan dalam Perspektif Islam, 43.

${ }^{33}$ Singgih D Gunarsa, Dasar-Dasar dan Teori Perkembangan Anak (Jakarta: BPK, Gunung Mulya, 1982), 140-141. 
anak yatim, yatim piatu dan terlantar, memberikan penguatan, menjadikan mereka tabah dan ikhlas, membuat anak-anak tersebut selalu berapikir positif serta dapat mengambil hikmah di setiap masalah kehidupannya. Dukungan dan motivasi tidak hanya diberikan dari lingkungan keluarga, sekolah dan masyarakat tetapi juga pemerintah.

Indonesia meratifikasi Konvensi Hak Anak melalui Keputusan Presiden No. 36/1990 tertanggal 25 Agustus 1990. Dengan ratifikasi tersebut, Indonesia secara teknis telah dengan sukarela mengikatkan diri pada ketentuan-ketentuan yang terkandung dalam Konvensi Hak Anak. Sesuai dengan Pasal 49 ayat 2, Konvensi Hak Anak dinyatakan berlaku di Indonesia sejak tanggak 5 Oktober 1990. Pemerintah juga mengeluarkan Peraturan Pemerintah No. 2 Tahun 1988 tentang Usaha Kesejahteraan Anak bagi Anak Yang Mempunyai Masalah. Anak yang mempunyai masalah adalah anak yang antara lain tidak mempunyai orang tua, anak terlantar, anak yang tidak mampu, anak yang mengalami masalah kelakuan dan anak cacat. Begitu pula dalam Undang Undang No. 4 Tahun 1979 tentang Kesejahteraan Anak Pasal 2 ayat (1), juga disebutkan bahwa anak berhak mendapatkan kesejahteraan, perawatan, asuhan, dan bimbingan berdasarkan kasih sayang baik dalam keluarganya maupun di dalam asuhan khusus untuk tumbuh dan berkembang dengan wajar. ${ }^{34}$

Kondisi sosial memiliki dampak yang sangat signifikan dalam meningkatkan motivasi anak-anak yatim, yatim piatu dan terlantar dengan adanya campur tangan dari orang-orang di lingkungan sekitarnya. Dengan begitu, mereka akan lebih bersemangat dalam belajarnya dan perlahan melupakan kesedihan yang dialaminya. Untuk itu, perlu perhatian dari semua pihak baik masyarakat, sekolah maupun pemerintah dalam mendukung setiap aktivitas mereka serta membimbing dan mengarahkannya pada kegiatan-kegiatan yang positif.

\section{PENUTUP}

\footnotetext{
${ }^{34}$ Vera Tanjun Kirana, PDF, http://eprints.umm.ac.id/34632/2/jiptummpp-gdl-veratanjun46338-2-babi.pdf (30 Mei 2018), 3.
} 
204 | MUSA WA, Vol. 12 No.2 Desember 2020 : 181-206

Dari keseluruhan uraian di atas mengenai Perkembangan Motivasi Pendidikan Anak dalam Tinjauan Sosial, maka Penulis mengemukakan beberapa kesimpulan sebagai berikut:

1. Dalam perkembagan Setiap manusia memiliki kebutuhan termasuk mislanya jika terjadi keterbatasan yang dimiliki anak seperti yatim piatu dan terlantar pada umumnya, tidak lantas secara keseluruhan membuatnya menjadi anak yang selalu bergantung pada orang lain, Anak atau individu dapat berkembang apabila peran orngtua dapat terealisasi dengan baik serta orang-orang terdekat di sekeliling anak seperti keluarga. , orang tua merupakan tempat pelindung yang paling aman dan nyaman. Setiap orang tua pasti menginginkan yang terbaik untuk anaknya baik bagi pertumbuhan maupun perkembangan juga dalam belajar sang anak, maka dari itu orang tua akan melakukan apa saja demi anak yang dicintainya. Sudah seharusnya seperti itu karena orang tua memiliki tanggung jawab penuh terhadap anak-anaknya yang merupakan amanah dari Allah yang harus dipenuhi kebutuhannya demi kelangsungan hidup anak tersebut. Oleh karena anak berhak untuk mendapatkan pendidikan sebagai kepedulian di mana anak senantiasa butuh bimbingan dan dorongan atau diberi motivasi dalam belajar sesuai dengan perkembangnya yang di harapkan oleh agama, bangsa dan negara.

2. Pada umumnya fakto-faktor yang mempengaruhi motivasi belajar Anak bukan hanya satu atau dua tetapi banyak faktor baik dari dalam (internal) maupun dari luar (eksternal). Manusia tidak terlepas dari kondisi sosial dimana merupakan sesuatu yang tidak terpisahkan dari kehidupan manusia itu sendiri. Kondisi sosial ini bisa baik atau bahkan sebaliknya, karena itulah kondisi sosial merupakan salah satu faktor yang besar pengaruhnya terhadap kehidupan manusia. Pada dasarnya anak yatim, yatim piatu dan terlantar sama dengan anak-anak pada umumnya tetapi ada perbedaan yang sangat mendasar yakni dari segi psikologisnya yang biasa disebut psikis anak. Perbedaan kondisi sosial inilah menjadi faktor yang paling berpengaruh terhadap anak-anak yatim, yatim piatu dan terlantar. Tidak sedikit dampak negatif yang diberikan oleh faktor kondisi sosial ini terhadap belajar anak-anak tersebut. Hal ini 
dikarenakan kondisi sosial merupakan sesuatu yang sangat berkaitan dengan kehidupan. Belajar dapat diartikan penguatan respon, mengubah pengetahuan peserta didik dalam bidang tertentu, sifat khusus, dan karakternya

3. Peran sosial sangat penting dalam meningkatkan motivasi belajar bagi Anak Yatim Piatu .meskipun difahami bahwa setiap manusia memiliki kebutuhan termasuk mislanya jika terjadi keterbatasan yang dimiliki anak seperti yatim piatu dan terlantar pada umumnya, ketiadaan kedua orang tuanya tidak lantas menjadikannya anak yang lemah serta mudah putus asa, namun karena hadirnya dukungan dari orang- orang yang ada disekitarnya atau kelompok sosial mereka mampuh menerima kondisi kehidupanya secara spontan menjadi. Oleh karena itu Kondisi sosial memiliki dampak yang sangat signifikan dalam meningkatkan motivasi anak-anak yatim, yatim piatu dan terlantar dengan adanya campur tangan dari orang-orang di lingkungan sekitarnya sehingga mereka akan lebih bersemangat dalam belajarnya karena dukungan dan perhatian dari semua pihak baik masyarakat, sekolah maupun pemerintah dalam mendukung setiap aktivitas mereka serta membimbing dan mengarahkannya pada kegiatan-kegiatan yang positif.

\section{DAFTAR PUSTAKA}

Ahmadi, Abu. Psikologi Umum, Cet. III; Jakarta: Rineka Cipta, 2003.

Darajad, Zakiah, et.al, Metodik Khusus Pengajaran Agama Islam, edisi kedua (. I; Jakarta: Bumi Aksara, 1995

Departemen Agama Republik Indonesia. Al-Qur'an dan Terjemahannya, Jakarta: CV. Atlas, 2000.

Gunarsa, Singgih D. Dasar-Dasar dan Teori Perkembangan Anak, Jakarta: BPK, Gunung Mulya, 1982.

Kartono, Kartini. Psikologi Anak (Psikologi Perkembangan), Cet. V; Bandung: Maju Mundur, 1995.

Moekijat. Dasar-Dasar Motivasi, Bandung: Pionir Jaya, 2002.

Monks, F.J, Knoers, A.M.P, dan Haditono, Siti Rahayu. Psikologi Perkembangan, Cet. XIIII; Yogyakarta: Gajah Mada University Press, 2002.

Mulyana, Rahmat. Mengartikulasi Pendidikan Nilai, Bandung: Alfabet, 2004. 
206 | MUSAWA, Vol. 12 No.2 Desember 2020 : 181-206

Mulyasa, E. Pengembangan dan Implementasi Kurikulum 2013, Cet. III; Bandung: Remaja Rosdakarya, 2013.

Noor Syam, Mohammad. Filsafat Pendidikan dan Dasar Filsafat Pendidikan Pancasila, Cet. IV; Surabaya: Usaha Nasional, 1988.

At.al. Pemikiran Pendidikan Islam, Cet. I; Jakarta: Pena Citasatria, 2007.

Rachmad K. Dwi Susilo, Sosiologi Lingkungan, Jakarta: RajaGrafindo Persada, 2008.

Sari, D. PDF, http://repository.uin-suska.ac.id/6201/2/BAB\%20I.pdf, 27 Mei 2018.

Sarwono, Sarlito Wirawan. Berkenalan dengan Aliran dan Tokoh-Tokoh Psikolog, Jakarta: Bulan Bintang, 1986.

Sahabuddin. Pendidikan Non Formal (Suatu Pengantar dalam Pemahaman Konsep dan Prinsip-Prinsip Pengembangan), Ujung Pandang: IKIP, 1983.

Slameto. Belajar dan Faktor-Faktor yang Mempengaruhiya, Cet. IV; Jakarta: Rineka Cipta, 2003.

Soerjono, Soekanto. 2004. Sosiologi Keluarga: Tentang Ikhwal Keluarga, Remaja Dan Anak, Jakarta: Raja grafindo persada.

Sumardi Suryabrata. Psikologi Pendidikan, Jakarta: DEPDIKBUD, 1983.

Surahmad, Winarno. Pendekatan dalam Proses Belajar Mengajar, Bandung: Remaja Rosdakarya, 1987.

Syah, Muhibbin. Psikologi Pendidikan dengan Pendekatan Baru, Cet. XII; Bandung: Remaja Rosdakarya, 2006.

Tafsir, Ahmad. Ilmu Pendidikan dalam Perspektif Islam, Cet. I; Bandung: Remaja Rosdakarya, 1992.

Tanjun Kirana, Vera. PDF, http://eprints.umm.ac.id/34632/2/jiptummpp-gdlveratanjun-46338-2-babi.pdf, 30 Mei 2018. 